特集記 事

\title{
プロテオーム解析に基づくビールオオムギ品質選抜法の開発
}

飯牟礼隆

サッポロビール株式会社価值創造フロンティア研究所, 静岡県焼津市岡当目 10, $=$ 425-0013

\section{Development of selection methods in malting barley breeding based on proteome analysis}

Takashi Iimure

Frontier Laboratories of Value Creation, Sapporo Breweries Ltd., Yaizu, Shizuoka 425-0013

キーワード

ビールオオムギ, ビール品質, プロテオーム解析, タンパク質, DNA マーカー

\section{1.はじめに}

ビールは古くから世界中で飲用されているアルコール 飲料の一つである. ビールの主原料はオオムギ（Hordeum vulgare L.) 由来の麦芽とホップ（Humulus lupulus）であ る.ビールは複雑な工程を経て醸造される。オオムギを 発芽させ麦芽を製造する製麦工程, 麦芽から発酵性糖を 抽出し，ホップを添加して煮沸することで麦汁を調製す る仕込工程, 酵母を添加してェタノール発酵を行ら発酵 工程，熟成を行う貯酒工程，さらに酵母などを除去する ろ過工程などにより成る。これらの各工程における技術 開発や適切な管理だけでなく, 原料の品質もビール品質 に影響する重要な要因であることが知られている.

ビールの「拈いしさ」は味や香りだけでなくその外観 も重要である。黄金の液色と白い泡のコントラストが見 た目の美しさを演出する。泡はビールの酸化やガスの揮 散を防ぐ役割もあるため, グラス等に注がれた泡の保持 性（泡持ち）はビールの重要な品質の一つとなっている. またビールは保存により濁りを生じることがあるが，こ れを防止することもビール醸造に和いて重要である。泡 持ちや混濁性はオオムギの栽培環境にも左右されるが, オオムギ品種によっても差が生じることから，これらは 遺伝形質でもあると考光られる（Evans and Hejgaard 1999, Robinson et al. 2007). ビールオオムギの育種では, 収量性や耐病性などの農業生産性，エキス分や発酵性な ぞの麦芽品質の向上が主な育種目標になっているが，育 種によるビール品質の向上も可能であると考えられる. しかし，ビール品質の向上を目的にした育種に拈いては 選抜に打ける課題がある。表現型に基づく選抜，すなわ ちオオムギの個体や系統ごとにビールを醇造し，泡持ち

2015 年 8 月 11 日受領 日本育種学会奨励賞受賞 (第 43 号) Correspondence: Takashi.Iimure@sapporobeer.co.jp
や混濁といった醸造形質を評価することは困難である。 ビールオオムギ育種に扣いてビールの醸造試験は育種の 最終段階で行われるのみであり，それは一般的には選抜 ではなく，評価と捉えられている（図 1).

DNA マーカーを利用した選抜は，育種の初期世代に対 して適応可能であり, 多検体を一度に選抜できるため, 多くの作物育種に拈いて利用されている。 ビールオオム ギ育種においても，耐病性（Pellio et al. 2005），休眠性 （Sato et al. 2009），麦芽のエキス分（Zhou et al. 2012）な ぞ多くの形質に対する DNA マーカーが開発され，育種 に掞いて利用されている. ビール品質に関するオオムギ DNA マーカーの開発には, 他の形質同様, QTL 解析や 全ゲノム関連解析（GWAS）といった遺伝解析的手法が 理論的には有効であるが，上述の通り，多数の系統につ いて泡持ちや混濁を評価するには多大な労力と時間が必 要であり，現実的とは言えない。これらの形質にはタン パク質が大きな影響を与えていることが知られており, 生化学的手法により品質関連タンパク質や遺伝子を同定 することが可能である. そのための手法として，タンパ ク質を網羅的に解析するプロテオーム解析が有効な手段 と考えられる. プロテオーム解析は近年の質量解析技術 の大幅な進歩により，様々な生物種，食品の分析に利用 されている. 図2 に示す通り，オオムギからビールに至 る醸造工程に拈いてプロテオームは劇的に変化する。ビー ル中のタンパク質からオオムギのタンパク質, そして遺 伝子まで工程を遡ることで, 醸造品質の遺伝的制御が可 能になると考えられる.

本研究では, ビールのプロテオーム解析を通じてビー ルの泡持ちおよび混濁に関連するタンパク質および遺伝 子を同定し，育種選抜に执いて汎用的に利用可能なビー ル品質関連 DNA マーカーを開発することを目指した（図 1). 

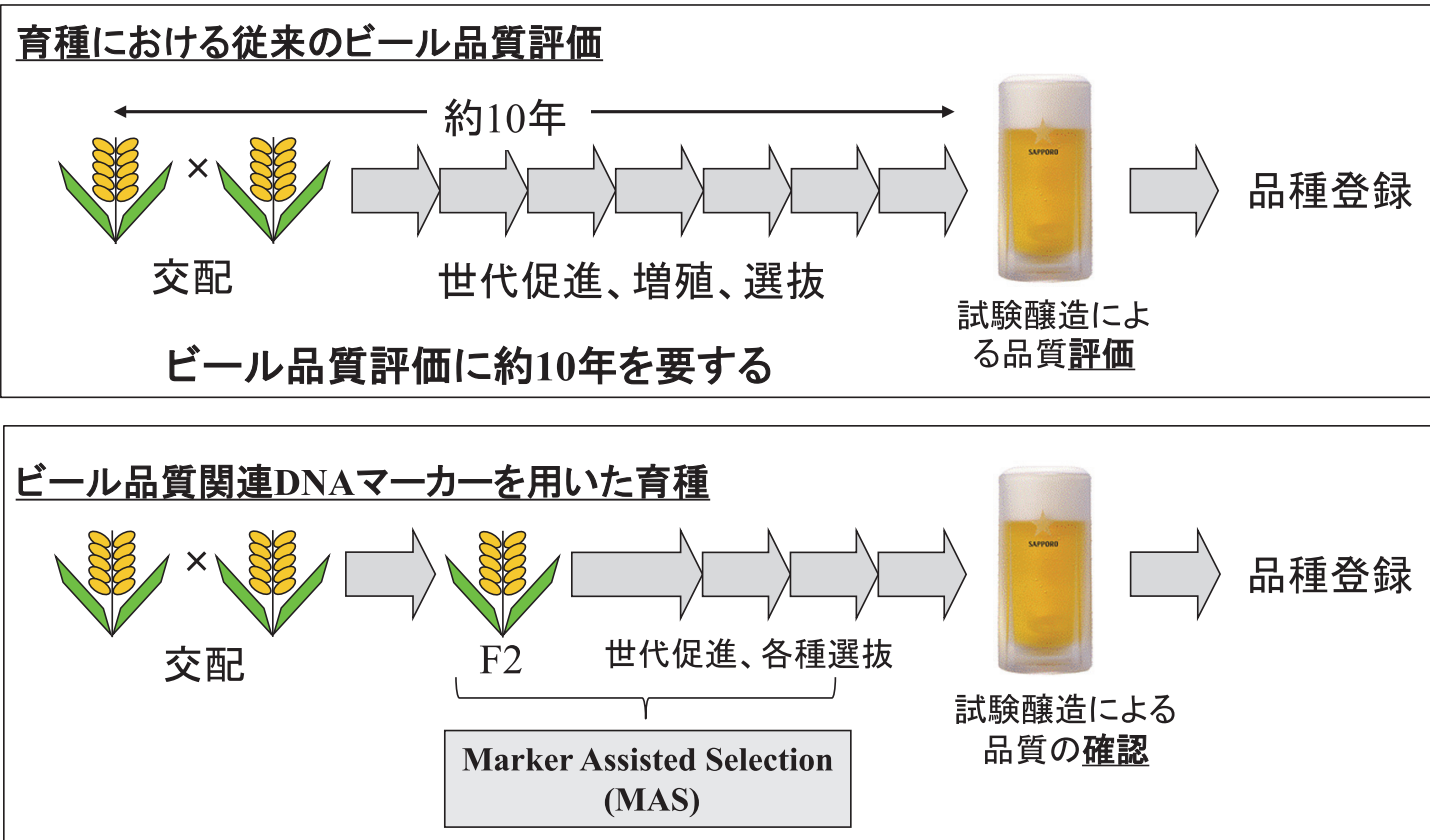

図 1. ビール品質関連 DNA マーカーを適応したビールオオムギ育種の流れ.

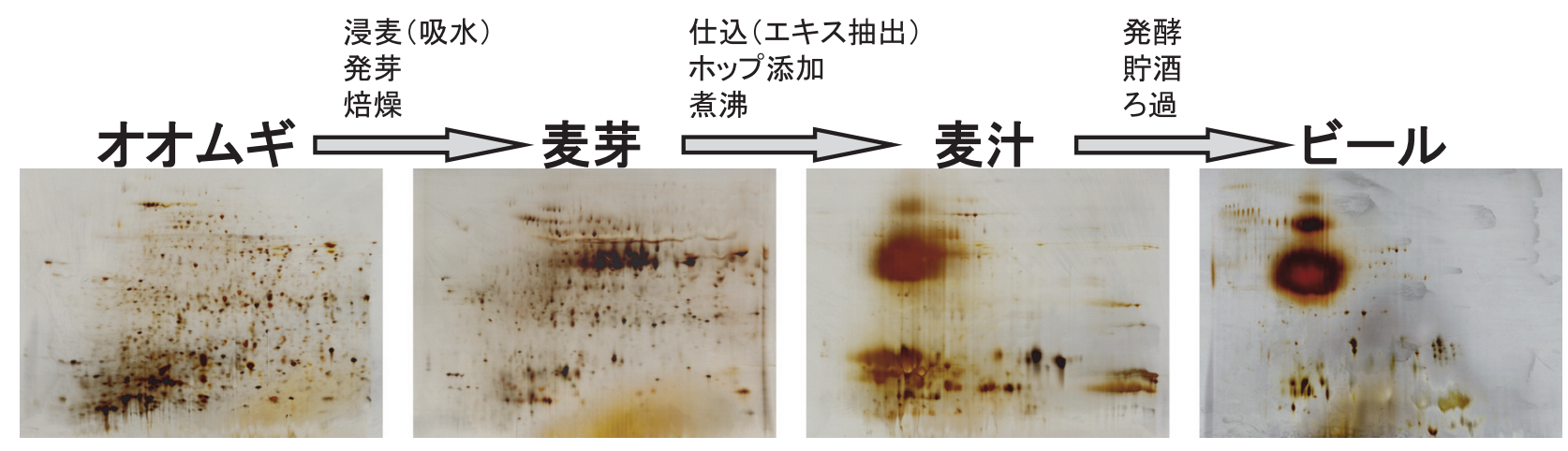

図 2. ビール醸造工程と二次元電気泳動解析により検出したプロテォーム変化.

\section{2. ビールおよび麦汁プロテオームマップの開発}

ビールに含まれるタンパク質は分子量約 $10 \mathrm{kDa}$ のオオ ムギ由来 lipid transfer protein 1（LTP1） と, 分子量約 40 $\mathrm{kDa}$ のセリンプロテアーゼインヒビターであるオオムギ 由来 protein Z type serpin（protein Z）が支配的であり，こ れらのタンパク質については泡持ちとの関与も示唆され ていることから詳細な解析が成されてきた（Evans and Hejgaard 1999, Maeda et al. 1991, Sørensen et al. 1993). 方で，泡持ちや混濁などのビール品質に関与するタンパ ク質はこれら 2 種のタンパク質だけではないと考兄られ た．品質に関連するビール中のタンパク質を同定するに 当たっては, 解析の基盤として, ビールタンパク質の組 成を理解する必要がある。そこで，プロテオーム解析を 通じて，ビールおよび発酵前の麦汁のタンパク質組成に 関する情報基盤を整備した。ビールおよび麦汁タンパク 質を二次元電気泳動で分離し，検出されたタンパク質ス ポット（ビールは 199 個，麦汁は 202 個）について質量
解析とデータベース検索によってタンパク質を同定した (Iimure et al. 2010, 2012)。これにより二次元電気泳動像 とタンパク質情報から成るビール拈よび麦汁プロテオー ムマップを開発できた。 原料であるオオムギ麦芽の違い によるビールプロテオームの差異を明らかにするために, 異なるオオムギ品種由来の麦芽から醸造したビール，お よび異なる麦芽製造（製麦）条件で調製した麦芽から醸 造したビールの二次元電気泳動解析を実施した。サンプ 几間の二次元電気泳動像の比較, およびビールプロテオー ムマップとの照合により, barley dimeric alpha amylase inhibitor-1 (BDAI-1), alpha-amylase/trypsin inhibitor $\mathrm{CMb}$ precursor 特よびLTP1などのオオムギ由来タンパク質, さらに thioredoxin; $\operatorname{Tr} x 2 \mathrm{p}$, yeast triosephosphate isomerase, enolase 1 といった酵母由来のタンパク質スポット濃度に 差が検出された（Iimure et al. 2010）。さらに，これらの ビールサンプルは泡品質および混濁性に違いが見られた ことから，醸造に用いるオオムギ品種拉よび製麦条件が ビールプロテオームの差を生み出し, その差がビール品 
質の差異に影響していることが推察された.

また，ホップの添加および者沸により発酵開始前の麦 汁が調製されるが，この際麦芽由来のタンパク質は変性 され，一部は凝固し，系外に除去されるため，煮沸工程 の条件（者沸温度や時間など）はビール品質に大きく影 響する。プロテオームマップを解析の基盤として, 煮沸 前および後の麦汁, さらに煮沸時の沈殿物の詳細なプロ テオーム解析を行ったところ, 煮沸工程において protein Z に麦芽由来の特定のペプチドが結合することにより protein Z が凝固, 沈殿することが示唆された（Iimure et al. 2012).

\section{3. 泡持ち関連タンパク質の同定と解析}

ビールの泡持ちは大麦品種や製麦条件によって差が生 じることが知られている．製麦工程ではオオムギ種子に 吸水させ発芽させるが，才オムギ種子の含水率（浸麦度） が高いとプロテアーゼ活性が高まり，才オムギ由来の夕 ンパク質の分解が促進される. タンパク質分解により生 じたアミノ酸は発酵工程において酵母の窒素源として重 要な役割を担う。一方で，オオムギ由来のタンパク質は ビールの泡持ちに重要な役割を果たして扣り，一般的に は浸麦度が増加するとビールの泡持ちは低下することが 知られている (Evans and Sheehan 2002). 発酵を円滑に進 めるためのアミノ酸を供給するために製麦時の浸麦度が 制御されるが，製麦に用いるオオムギ品種としては発酵 に支障を来さない量のアミノ酸を供給し，かつ泡持ちも 良い品種が望ましいと言える。日本と北米のビールオオ ムギ，それぞれ 2 品種，1品種について浸麦度を変えて 製麦を行い，それぞれの麦芽を単独で用いた醸造試験を 実施した。 その結果, 日本の 2 品種は浸麦度が増加する と泡持ちは低下したが，北米品種は浸麦度によらず泡持 らが高いレベルで一定であるといら特異な性質を示した (Okada et al. 2008). この性質はアミノ酸を十分に供給 し，かつ泡持ちの良いビールを醸造する上では有用なも のである. 泡持ちに関与するタンパク質は一般的に疎水 性が高く, 泡に濃縮される性質を有すると考えられる. 試験した北米品種の泡持ちが良い性質の原因を明らかに するために，各サンプルのビール中に含まれる全タンパ ク質, 疎水性タンパク質を多く含むと考兄られる $25 \%$ 飽 和硫酸アンモニウム沈殿画分，さらにビールの泡に濃縮 される画分それぞれについて二次元電気泳動解析を行っ たところ, 分子量約 $12 \mathrm{kDa}$ の一連のタンパク質スポット が北米品種由来のビールでは浸麦度によらず明瞭に検出 できたのに対し，日本の 2 品種では浸麦度の増加ととも に減少，もしくは低浸麦度でも薄いスポットのみが確認 できた。 これらタンパク質スポットが泡持ちに関与する タンパク質候補であることが示唆されたため, これらの タンパク質スポットの質量解析拈よびデータベース検索 を行ったところ, 全てのスポットが barley dimeric alpha amylase inhibitor-1（BDAI-1）と同定された（Iimure et al. 2008). さらに, 塩析执よびカラムクロマトグラフィーに よりビールから BDAI-1 を精製した。この精製 BDAI-1 をビールに添加したところ, 添加量依存的に泡持ちが向 上したことから，BDAI-1 は泡持ちに直接作用するタンパ ク質であることが示された（Iimure et al. 2015）. BDAI-1 は新規な泡持ち関連タンパク質である.

ビール中に最も多く含まれるタンパク質は protein Zで あり, protein Zは表面粘度および弾力性が高いタンパク 質であるとされている（Maeda et al. 1991）. protein Zに はZ4，Z7 およびZxの3つのサブファミリーが存在する が，ビール中では protein Z4 と Z7 が支配的であり， Zx はわずかに存在するのみである (Fasoli et al. 2010, Konečná et al. 2012). ビール中の Z4 と Z7 の存在比率は用いる才 オムギ品種に依存することが明らかになっている（Evans and Hejgaard 1999, Iimure et al. 2011). protein Z4 およよび Z7 をそれぞれ特異的に認識する抗体を用いて，ビール中の protein Z4 抢よび Z7 含量とビールの泡持ちの関係を調査 したところ, protein Z4 は泡持ちと正の, protein Z7 は負 の有意な相関関係が確認された（Iimure et al. 2011）.

ホルディンはオオムギ種子中の主要なタンパク質であ る. ホルデインは分子量によって B, C, D, $\gamma$ ホルディ ンに分類される（Skerritt and Janes 1992）。 B ホルディン はホルディンの 70-80\%を, C ホルディンは 10-12\%を占 め, D拈よび $\gamma$ ホルデインの比率は低い. ホルデインは 製麦, 仕込工程で低分子化され, 一部がビール中に移行 することが知られている. 近年のビールプロテオーム解 析により，低分子化された様々なアミノ酸配列を有する ホルディン由来ペプチドが検出されている (Colgrave et al. 2012, Picariello et al. 2011, Weber et al. 2009). 本研究で はB ホルディンと泡持ちの関係を詳しく調べた. B ホル ディン欠失系統（Risø 56）を CDC Kendall に2 回戻し交 雑した系統を育成した。 2 つ異なる環境下で栽培した オオムギからそれぞれ麦芽を調製し, 醸造試験を行った ところ，B ホルディン欠失系統は対照と比較して泡持ち が低下したことから，B ホルデインは泡持ちに関与する タンパク質であることが示唆された. また， B ホルデイ ンのアリル，すなわちオオムギ種子タンパク質の SDSPAGE で検出される B ホルディン型と泡持ちの関係を明 らかにするために，ミカモゴールデン-Harrington の倍加 半数体 95 系統を B ホルディン型により 2 つの集団に分 け，それぞれの型でバルク集団を調製し，3つの異なる 環境下で栽培したオオムギから麦芽を調製後, 醸造試験 を実施した。 B ホルデインがミカモゴールデン型の系統 は Harrington 型と比較して有意に泡持ちが良かったこと から, 泡持ちの良いビールオオムギ育種に扮いて $\mathrm{B}$ ホル ディンがミカモゴールデン型のものを選抜することが好 ましいことが示唆された。 

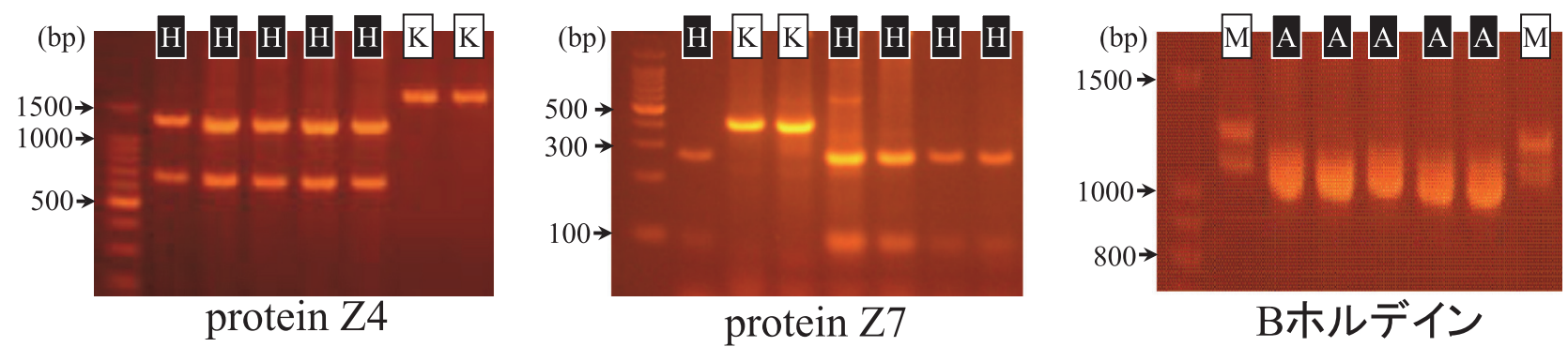

図 3. protein Z4, protein $\mathrm{Z} 7$ および $\mathrm{B}$ ホルデインの CAPS マーカー.

$\mathrm{H}$ ：はるな二条型（低泡持ち）, K : CDC Kendall 型（高泡持ち), A : Harrington 型（低泡持ち), M : ミカモゴールデン型（高泡 持ち).

\section{4. 泡持ち関連 DNA マーカーの開発}

3 つの異なる環境で栽培した 23 品種のオオムギ種子中 の protein Z4 拉よび Z7 含量を定量したところ, 品種間差 が認められた（Iimure et al. 2011）。そこで protein Z4 特よ びZ7 含量が高い 3 品種, 低い 3 品種それ卆れの構造遺 伝子の一部拉よびプロモーターを含むと考光られる5'側 の塩基配列を調査した. protein Z4 については翻訳開始コ ドンより 5 側に SNPs を含む 5 つの多型を検出した。 こ のらち 1 つの SNP に制限酵素認識配列が含まれたため, この多型を標的とした cleaved amplified polymorphic sequence（CAPS）マーカーを開発した（図 3)。また, protein Z7 については，翻訳開始コドンょり 5'側の塩基配 列が $29 \mathrm{bp}$ しか公開さ扎ていなかったため, thermal asymmetric interlaced（TAIL）PCR を行い，307 bp の新規 な塩基配列情報を取得した。 これらの領域に 23 個の多型 を検出できた。このらち制限酵素認識配列を含む多型を 標的としてCAPS マーカーを開発した（図 3)。これらの DNA マーカーで同定された遺伝子型により，オオムギ種 子中の protein $\mathrm{Z} 4$ 抢よび $\mathrm{Z} 7$ 含量の平均值に有意な差があ ることが確認された，さらに，11 品種の麦芽をそれぞれ 単独で使用して醸造したビールの泡持ちの各マーカーの 遺伝子型による平均值に有意な差が認められた（Iimure et al. 2011). 以上のことから，泡持ちの良いオオムギを 選抜する上で本 DNA マーカーは有効であることが示唆 された。 また，日本，北米，豪州，欧州のビールオオム ギ 64 品種について protein Z4 抒よび Z7 の遺伝子型を調 查したところ，2つの遺伝子に打いて，ともに泡持ちの 良いアリルを有する品種は北米，欧州に多く，調査した 中では日本には 1 品種しか存在しなかった.

既知の B ホルデイン塩基配列のらち，登熟中に発現す ることが確認されている遺伝子の塩基配列情報をもとに, 品種間の多型を検出し，CAPS マーカーを開発した（図 3). 泡持ちの良いミカモゴールデン型は日本の品種に多 く確認された。このため，主として北米拈よび欧州品種 が有する protein Z4 打よび Z7 の高泡持ちアリルと，日本 品種が有する B ホルデインの高泡持ちアリルを集積する ことで，より泡持ちの良い品種を育成することが可能で
あると考兄られる。一方，ビールの好ましくない香りの 原因物質の前駆体の 1 つとされる S-メチルメチオニン （SMM）含量の QTL 解析により，B ホルデイン遺伝子近 傍に QTL が検出されている（Zhou et al. unpublished data). 高泡持ち性となる B ホルデインミカモゴールデン 型を有するオオムギは，その大部分が高 SMM となるが， 北海道向け育成系統の中から，B ホルデインがミカモゴー ルデン型かつ低 SMM である北系 0685 を見出した. 本系 統を交配母本として利用することで，高泡持ちかつ低 SMM となるビールオオムギの育成が期待される.

\section{5. 混濁関連タンパク質の同定}

長期保存により混濁した 4 種のビールサンプルから混 濁物を回収し，その中に含まれるタンパク質を二次元電 気泳動で分離し，質量解析とデータベース検索で同定し たしたところ，4つのサンプルで共通して検出されたタ ンパク質として BDAI-1， CMb component of tetrameric alpha amylase inhibitor $(\mathrm{CMb})$ 预よび trypsin inhibitor $\mathrm{CMe}$ precursor（CMe）が同定された（Iimure et al. 2009）。混濁 物中タンパク質と同定されたタンパク質のアミノ酸組成 比較，沶よび混濁関連タンパク質が吸着するとされるシ リカゲルに吸着したタンパク質のプロテオーム解析の結 果から，これらのタンパク質は混濁の核ではなく，混濁 を成長させる因子であることが示唆された（Iimure et al. 2009). BDAI-1 おちよび CMb は新規な混濁関連タンパク 質であり，これらを遺伝的に制御することで，混濁のよ り少ないビールオオムギの開発が可能になることが期待 される。

\section{6. おわりに}

ビール醇造に携わる研究者や技術者の弛ま 努力に よって，今日では高い品質のビールを安定的に製造する ことが可能になった，一方で，更なる高品質化も求めら 孔て扮り, 現在子鋭意研究・開発が進められている. 様々 なアプローチがある中で, 本研究では生化学的解析の結 果をビールオオムギ育種に応用することで，育種によっ 
てビール品質を向上できる可能性を示すことができた. 評価に多大な労力を必要とする醸造形質に対して, DNA マーカーによる選抜を適用することは育種の選抜に掞い て大きな威力を発揮する。 また, 本研究で開発したDNA マーカーを用いて，好ましいアリルを集積することが可 能になると考えられる。ささらに, 本研究で同定した泡品 質や混濁に関連するタンパク質和よび遺伝子の情報を元 に，ビール品質をより向上させるアリルを遺伝資源から スクリーニングする， あるいは突然変異により得るなど のアプローチが可能である。農業形質や麦芽品質と合わ せて，醸造形質に関してもDNA マーカーによる選抜を 行らことで, より高品質なビールオオムギ，そしてさら に高い品質を有するビールを醸造できるようになること を期待したい.

\section{謝 辞}

本研究は多くの方々のご支援，ご協力拉よびご指導の もと遂行することができたものである．特に岡山大学の 佐藤和広教授には本研究を全面的にご支援頂き，多大な るご指導を賜った。岡山大学の武田和義名誉教授には研 究に対する姿勢などをご教授頂いた。 また東京大学の岩 田洋佳准教授, サッポロビール株式会社バイオ研究開発 部，価值創造フロンティア研究所，括よび商品・技術開 発センターの方々には試験材料育成, 麦芽の調製, 分析, 試験醸造，データ解析の手法など多方面にわたってご協 力，ご支援を頂いた．皆様方にここに深謝申し上げる. 本研究は科学技術振興機構の戦略的創造研究推進事業 （CREST）㧊よび生物系特定産業技術研究支援センター の基礎研究推進事業の支援のもと行われたものである.

\section{引用文献}

Colgrave, M.L., H. Goswami, C.A. Howitt and G.J. Tanner (2012) What is in a beer? Proteomic characterization and relative quantification of hordein (gluten) in beer. J. Proteome Res. 11: 386-396.

Evans, D.E. and J. Hejgaard (1999) The impact of malt derived proteins on beer foam quality Part I: The effect of germination and kilning on the level of protein Z4, protein Z7 and LTP1. J. Inst. Brew. 105: 159-169.

Evans, D.E. and M.C. Sheehan (2002) Don't be fobbed off, substance of beer foam, a review. J. Am. Soc. Brew. Chem. 60: 47-57.

Fasoli, E., G. Aldini, L. Regazzoni, A.V. Kravchuk, A. Citterio and P.G. Righetti (2010) Les Maîtres de l'orge: The proteome content of your beer mug. J. Proteome Res. 9: 5262-5269.

Iimure, T., K. Takoi, T. Kaneko, M. Kihara, K. Hayashi, K. Ito, K. Sato and K. Takeda (2008) Novel prediction method of beer foam stability using protein $\mathrm{Z}$, barley dimeric $\alpha$-amylase inhibitor-1 (BDAI-1) and yeast thioredoxin. J. Agric. Food Chem. 56: 8664-8671.

Iimure, T., N. Nankaku, M. Watanabe-Sugimoto, N. Hirota, Z. Tiansu, M. Kihara, K. Hayashi, K. Ito and K. Sato (2009) Identification of novel haze-active beer proteins by proteome analysis. J.
Cereal Sci. 49: 141-147.

Iimure, T., N. Nankaku, N. Hirota, Z. Tiansu, T. Hoki, M. Kihara, H. Hayashi, K. Ito and K. Sato (2010) Construction of a novel beer proteome map and its use in beer quality control. Food Chem. 118: 566-574.

Iimure, T., M. Kihara, S. Ichikawa, K. Ito, K. Takeda and K. Sato (2011) Development of DNA markers associated with beer foam stability for barley breeding. Theor. Appl. Genet. 122: 199-210.

Iimure, T., N. Nankaku, M. Kihara, S. Yamada and K. Sato (2012) Proteome analysis of the wort boiling process. Food Res. Intern. 45: 262-271.

Iimure, T., M. Kihara, K. Sato and K. Ogushi (2015) Purification of barley dimeric $\alpha$-amylase inhibitor-1 (BDAI-1) and avenin-like protein-a (ALP) from beer and their impact on beer foam stability. Food Chem. 172: 257-264.

Konečná, H., L. Müller, H. Dosoudilová, D. Potěšil, J. Buršíková, O. Šedo, I. Márová and Z. Zdráhal (2012) Exploration of beer proteome using OFFGEL prefractionation in combination with two-dimensional gel electrophoresis with narrow $\mathrm{pH}$ range gradients. J. Agric. Food Chem. 60: 2418-2426.

Maeda, K., S. Yokoi, K. Kamada and M. Kamimura (1991) Foam stability and physicochemical properties of beer. J. Am. Soc. Brew. Chem. 49: 14-18.

Okada, Y., T. Iimure, K. Takoi, T. Kaneko, M. Kihara, K. Hayashi, K. Ito, K. Sato and K. Takeda (2008) The influence of barley malt protein modification on beer foam stability and their relationship to the barley dimeric $\alpha$-amylase inhibitor-I (BDAI-I) as a possible foam-promoting protein. J. Agric. Food Chem. 56: $1458-1464$.

Pellio, B., S. Streng, E. Bauer, N. Stein, D. Perovic, A. Schiemann, W. Friedt, F. Ordon and A. Graner (2005) High-resolution mapping of the Rym4/Rym5 locus conferring resistance to the barley yellow mosaic virus complex (BaMMV, BaYMV, BaYMV-2) in barley (Hordeum vulgare ssp. vulgare L.). Theor. Appl. Genet. 110: 283-293.

Picariello, G., F. Bonomi, S. Iametti, P. Rasmussen, C. Pepe, S. Lilla and P. Ferranti (2011) Proteomic and peptidomic characterization of beer: Immunological and technological implications. Food Chem. 124: 1718-1726.

Robinson, L.H., P. Healy, D.C. Stewart, J.K. Eglinton, C.M. Ford and D.E. Evans (2007) The identification of a barley haze active protein that influences beer haze stability: The genetic basis of a barley malt haze active protein. J. Cereal Sci. 45: 335-342.

Sato, K., T. Matsumoto, N. Ooe and K. Takeda (2009) Genetic analysis of seed dormancy QTL in barley. Breed. Sci. 59: 645650.

Skerritt, J.H. and P.W. Janes (1992) Disulphide-bonded gel protein aggregates in barley: quality-related differences in composition and reductive dissociation. J. Cereal Sci. 16: 219-235.

Sørensen, S.B., L.M. Bech, M. Muldbjerg, T. Beenfeldt and K. Breddam (1993) Barley lipid transfer protein 1 is involved in beer foam formation. Tech. Quart. Master Brew. As. Am. 30: 136-145.

Weber, D., C. Cléroux and S.B. Godefroy (2009) Emerging analytical methods to determine gluten markers in processed foodsmethod development in support of standard setting. Anal. Bioanal. Chem. 395: 111-117.

Zhou, T.S., T. Iimure, R. Kanatani, N. Hirota, M. Kihara, T. Hoki and K. Sato (2012) Malting quality quantitative trait loci on a highdensity map of Mikamo golden $\times$ Harrington cross in barley (Hordeum vulgare L.). Mol. Breed. 30: 103-112. 